\title{
B chromosomes in a population of Astyanax eigenmanniorum (Characiformes, Characidae) from the Araguari River Basin (Uberlândia, MG, Brazil)
}

\author{
Alessandra Ribeiro Torres-Mariano and Sandra Morelli \\ Instituto de Genética e Bioquímica, Universidade Federal de Uberlândia, Uberlândia, MG, Brazil.
}

\begin{abstract}
A cytogenetic study was conducted on an Astyanax eigenmanniorum population from the Caetano Stream (18 44' 56" S/ 048 18' 39" W) - in Uberlândia, MG, Brazil - showing a modal diploid number of 48 chromosomes in the standard male and female karyotypes. However, in several specimens it was also possible to observe metaphases with one or two B chromosomes, increasing the diploid number to 49 or 50 chromosomes, respectively. The supernumerary chromosomes were totally heterochromatic and highlighted after C-banding. The silver-stained nucleolus organizing regions (Ag-NORs) were located in at least five chromosomes of the standard karyotype, thus characterizing a multiple NOR system in the species. This is the first occurrence of an $A$. eigenmanniorum population with $2 \mathrm{n}=48$ chromosomes, bearing supernumerary chromosomes.
\end{abstract}

Key words: Characidae, Astyanax eigenmanniorum, supernumerary chromosome, heterochromatin, nucleolus organizing regions (NORs).

Received: August 18, 2006; Accepted: May 22, 2007.

Preliminary cytogenetic studies in Brazilian Astyanax species were initiated in the late 1970s by Foresti et al. (1977). Further studies confirmed that the chromosomal number in this fish group ranges from $2 \mathrm{n}=36$ in $A$. schubarti (Morelli et al., 1983) to $2 \mathrm{n}=50$ in A. altiparanae (Pacheco et al., 2001; Fernandes and Martins-Santos, 2004) and A. eigenmanniorum (Stripecke et al., 1985; Fauaz et al., 1994; Pfister and Moreira-Filho, 1997). A. scabripinnis (Morelli et al., 1983; Araujo and Morelli, 2006), A. fasciatus (Morelli et al., 1983; Torres-Mariano and Morelli, 2006), and A. altiparanae correspond to the species with the highest number of cytogenetic studies.

Karyotypic variability among different Astyanax fish populations is very common and, in some cases, the presence of different numbers of chromosomes has been found among individuals of the same population, such as in $A$. fasciatus (Pazza et al., 2006) and A. scabripinnis (Kavalco and Moreira-Filho, 2003; Fernandes and Martins-Santos, 2005).

Supernumerary or B chromosomes are additional dispensable chromosomes that are present in some individuals from some populations in some species, which have probably arisen from the A (standard) chromosomes but follow their own evolutionary pathway (Camacho et al., 2000).

Send correspondence to Alessandra Ribeiro Torres-Mariano. Rua Doutor Lacerda 195, Bairro Lídice, 38000-088 Uberlândia, MG, Brazil. E-mail: aribeirotorres@yahoo.com.br.
These chromosomes may constitute an alternative form of organization of the genetic material and can be considered true parasites, remaining in populations exclusively by means of their distinctive transmission mechanisms (Rejón et al., 1987).

B chromosomes can be found in haploid or diploid organisms, and can be seen totally or partially heterochromatic (Jones, 1991), after the C-banding technique (Sumner, 1972). However, although very common, these characteristics are not present in all B chromosomes (Beukeboom, 1994). Among fishes, the most studied species is A. scabripinnis, which presents macro- and micro-supernumerary chromosomes with a frequency that varies between males and females and according to the altitude at which populations occur (Salvador and Moreira-Filho, 1992; Vicente et al., 1996; Néo et al., 2000; Mestriner et al., 2000; Ferro et al., 2003; Moreira-Filho et al., 2004; Araujo and Morelli, 2006).

This paper gives the description of a large metacentric supernumerary chromosome in A. eigenmanniorum from the Caetano Stream (18 44' 56" S/ 048 18' 39" W, Uberlândia, MG, Brazil). Thirteen specimens (five males, seven females, and one unsexed) were cytogenetically analyzed. The animals were identified by Dr. Valdener Garutti (UNESP, São José do Rio Preto, SP), and further registered and deposited in the fish collection of the Laboratory of Animal Cytogenetics, at the Federal University of Uberlândia. 
Mitotic chromosomes were obtained according to Bertollo et al. (1978). Nucleolus organizer regions (AgNORs) were identified following the procedure described by Howell and Black (1980). Constitutive heterochromatin was detected using the C-banding technique (Sumner, 1972). The chromosome morphology was determined on the basis of the arm ratio (AR), as proposed by Levan et al. (1964), and the chromosomes were classified as metacentric $(\mathrm{m})$, submetacentric $(\mathrm{sm})$, subtelocentric (st), and acrocentric (a).

A. eigenmanniorum presented a standard karyotype with a diploid number of $2 n=48$ chromosomes, both in males and females (Table 1) and a karyotype composed of 7 pairs of metacentric (m), 9 pairs of submetacentric (sm), 5 pairs of subtelocentric (st), and 3 pairs of acrocentric (a) chromosomes (Figure 1a). However, in several specimens it was also possible to observe metaphases with one or two B chromosomes, increasing the diploid number up to 49 chromosomes or 50 chromosomes (Table 1). In three females the proportion between 48 and 49 chromosomes was very similar (Table 1). The metaphases with 49 and 50 chromosomes showed the presence of one or two large metacentric supernumerary chromosomes, respectively (Figure 1b, c), corresponding in size to the second chromosome pair of the A complement, which proved to be totally heterochromatic when subjected to C-banding (Figure 1e). The other chromosomes showed heterochromatin located at the telomeric and/or centromeric regions, as well as in the whole short arm (Figure 1e). Although two male specimens (n. 584 and 623) showed $2 \mathrm{n}=49$ chromosomes, a low metaphase index was found with this chromosome number (Table 1), and they did not present completely heterochromatic chromosomes after C-banding. Thus, the extra chromosome found in these cases appears only to be a lost chromosome from another standard metaphase.

A. eigenmanniorum is characterized by a multiple NOR system. Indeed, Ag-NORs were seen in different chromosome pairs of the standard karyotype. In the first pair of submetacentric chromosome it is also evident a size polymorphism between the homologous NORs, but with a low frequency (Figure 1d).

Data from only three A. eigenmanniorum populations have been described to date (Stripecke et al., 1985; Fauaz et al., 1994; Pfister and Moreira-Filho, 1997), all with $2 \mathrm{n}=50$

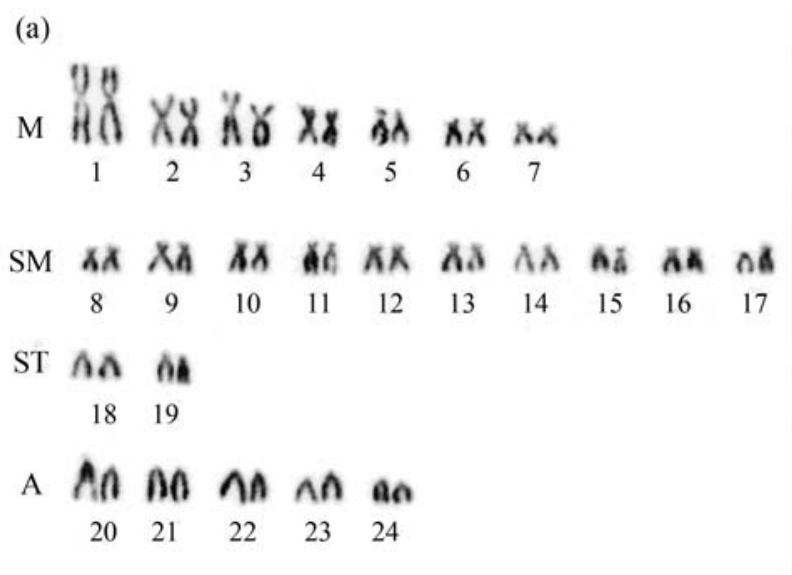

(b)

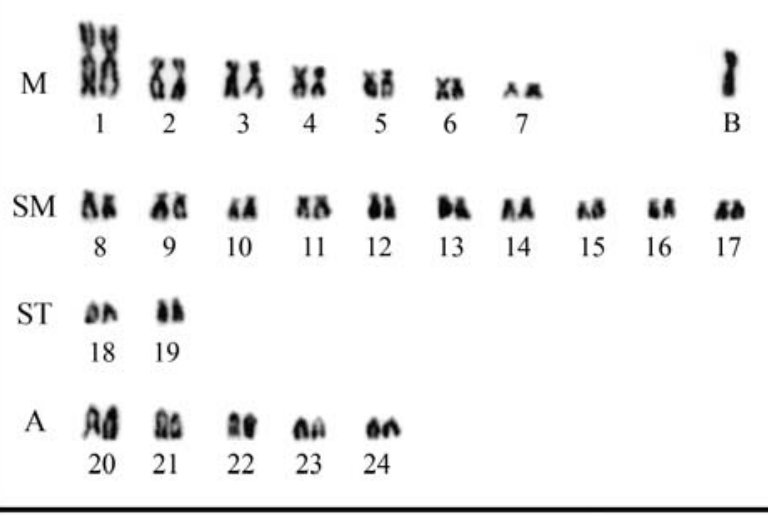

(d)

(e)

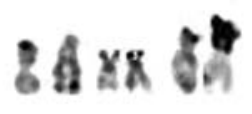

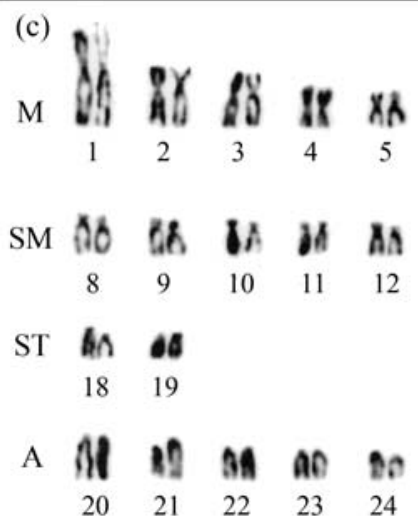

Figure 1 - Karyotypes of A. eigenmanniorum from the Caetano Stream, presenting 48 chromosomes (a), 49 chromosomes with 1 B chromosome (b), and 50 chromosomes with $2 \mathrm{~B}$ chromosomes (c). In (d) Ag-NOR bearing chromosomes - from left to right: $3^{\text {rd }}$ metacentric chromosome, an acrocentric chromosome (which is rarely detected), $4^{\text {th }}$ metacentric pair, and $1^{\text {st }}$ submetacentric pair, highlighting the size polymorphism of the NOR site. In (e) C-banded metaphase: the small black arrow indicates the heterochromatic supernumerary chromosome; the thick white one indicates the metacentric NOR bearing chromosome. 
Table 1 - Chromosome number frequency found in Astyanax eigenmanniorum from the Caetano Stream.

\begin{tabular}{lrrrrrr}
\hline \multirow{2}{*}{ Specimen registration } & \multicolumn{5}{c}{ Sex and diploid chromosome number } \\
\cline { 2 - 7 } & sex & 46 & 47 & 48 & 49 & 50 \\
\hline 577 & M & 8 & 11 & 18 & & \\
578 & M & 8 & 7 & 20 & & \\
584 & M & 6 & 2 & 29 & 1 & \\
623 & M & 6 & 9 & 22 & 2 & \\
581 & F & 7 & 4 & 18 & 6 & \\
583 & F & 12 & 7 & 33 & 39 & 1 \\
613 & F & 0 & 3 & 7 & 18 & 2 \\
617 & F & 6 & 4 & 13 & 14 & 6 \\
620 & F & 3 & 8 & 4 & 21 & 4 \\
622 & F & 6 & 8 & 9 & 19 & 1 \\
1314 & F & 4 & 4 & 17 & 12 & 1 \\
\hline Total number of cells & & 66 & 67 & 190 & 132 & 15 \\
\hline
\end{tabular}

M: male. F: female.

chromosomes. Some triploid specimens were found in populations of the Grande River, MG (Fauaz et al., 1994), and only one female from Atibaia River population showed a B chromosome whose size corresponds to that found in the present paper (Stripecke et al., 1985). In the $A$. eigenmanniorum population from the Caetano Stream, the presence of at least one totally heterochromatic B chromosome was evidenced in several specimens. It is also interesting to note that these specimens presented inter- and intra-individual variation in chromosome number (Table 1), suggesting a recent origin for the $\mathrm{B}$ chromosomes in this population.

This paper also describes, for the first time, the presence of supernumerary chromosomes in an $A$. eigenmanniorum population with the diploid number equal to 48 chromosomes.

\section{Acknowledgments}

We are indebted to Dr. Valdener Garutti for identifying the specimens and to the financial support from CAPES, CNPq, FAPEMIG, and UFU (Brazil).

\section{References}

Araujo ACS and Morelli S (2006) Comparação citogenética de duas populações de Astyanax scabripinnis (Pisces, Characidae) da região do Triângulo Mineiro. Biosci J 22:145-150.

Bertollo LAC, Takahashi CS and Moreira-Filho O (1978) Cytotaxonomic considerations on Hoplias lacerdae (Pisces, Erythrinidae). Rev Bras Genet 1:103-120.

Beukeboom LW (1994) Bewildering B: An impression of the 1st B-chromosome conference. Heredity 73:328-336.

Camacho JP, Sharbel TF and Beukeboom LW (2000) B-chromosome evolution. Phil Trans R Soc Lond 355:163-178.
Fauaz G, Vicente VE and Moreira-Filho O (1994) Natural triploidy and B chromosomes in the neotropical fish genus Astyanax (Characidae). Rev Brasil Genet 17:157-163.

Fernandes CA and Martins-Santos IC (2004) Cytogenetics study in two populations of Astyanax altiparanae (Pisces, Characiformes). Hereditas 141:328-332.

Fernandes CA and Martins-Santos IC (2005) Sympatric occurrence of three cytotypes and four morphological types of $\mathrm{B}$ chromosomes of Astyanax scabripinnis (Pisces, Characiformes) in the River Ivaí Basin, state of Paraná, Brazil. Genetica 124:301-306.

Ferro DAM, Moreira-Filho O and Bertollo LAC (2003) B chromosome polymorphism in the fish, Astyanax scabripinnis. Genetica 119:147-153.

Foresti F, Toledo-Filho AS and Ribeiro AF (1977) Chromosomal and biochemical genetic studies in Astyanax (Pisces, Characidae). Anais do III Latin American Congress of Genetics, Montevideo, Uruguay.

Howell WM and Black DA (1980) Controlled silver-staining of nucleolus organizer regions with a protective colloidal developer: A 1-step method. Experientia 36:1014-1015.

Jones RN (1991) B-chromosome drive. Am Nat 137:430-432.

Kavalco KF and Moreira-Filho O (2003) Cytogenetic analyses of four species of the genus Astyanax (Pisces, Characidae) from the Paraíba do Sul River Basin. Caryologia 56:453-461.

Levan A, Fredga K and Sandberg AA (1964) Nomenclature for centromeric position on chromosome. Hereditas 52:201-220.

Mestriner CA, Galetti Jr PM, Valentini SR, Ruiz IRG, Abel LDS, Moreira-Filho O and Camacho RPM (2000) Structural and functional evidence that a $\mathrm{B}$ chromosome in the characid Astyanax scabripinnis is an isochromosome. Heredity 85:1-9.

Morelli S, Bertollo LAC, Foresti F, Moreira-Filho O and Toledo-Filho SA (1983) Cytogenetic considerations on the genus Astyanax (Pisces, Characidae). I Karyotypic variability. Caryologia 36:235-244.

Moreira-Filho O, Bertollo LAC and Galetti Jr PM (2004) B chromosome in the fish Astyanax scabripinnis (Characidae, Tetragonopterinae): An overview in natural populations. Cytogenet Genome Res 106:230-234.

Néo MD, Moreira-Filho O and Camacho JPM (2000) Altitudinal variation for B chromosome frequency in the characid fish Astyanax scabripinnis. Heredity 85:136-141.

Pacheco RB, Giuliano-Caetano L and Dias AL (2001) Cytotypes and multiple NOR in an Astyanax altiparanae population (Pisces, Tetragonopterinae). Chrom Sci 5:109-114.

Pazza R, Kavalco KF and Bertollo LAC (2006) Chromosome polymorphism in Astyanax fasciatus (Teleostei, Characidae).1. Karyotype analysis, Ag-NORs and mapping of the $18 \mathrm{~S}$ and $5 \mathrm{~S}$ ribosomal genes in sympatric karyotypes and their possible hybrid forms. Cytogenet Genome Res 112:313-319.

Pfister SC and Moreira-Filho O (1997) Caracterização citogenética de uma população de Astyanax eigenmanniorum. Brazil J Genet (suppl) 20:101.

Rejón MR, Rejón CR and Oliver JL (1987) Evolucion de los cromosomas B. Investigacion y Ciencia 133:92-101.

Salvador LB and Moreira-Filho O (1992) B chromosome in Astyanax scabripinnis (Pisces, Characidae). Heredity 69:50-56.

Stripecke R, Nogueira-Pinto MT, Hackel C and Sazima I (1985) O cariótipo de Astyanax eigenmanniorum (Osteichthyes, 
Characidae). XII Congresso Brasileiro de Zoologia pp 173 Campinas, Brazil.

Sumner AT (1972) A simple technique for demonstrating centromeric heterochromatin. Exp Cell Res 74:304-306.

Torres-Mariano AR and Morelli S (2006). Chromosome analysis in Astyanax fasciatus (Pisces, Characidae) from Araguari River, Uberlândia, MG. Braz J Biol 66:161-165.
Vicente VE, Moreira-Filho O and Camacho JPM (1996) Sex-ratio distortion associated with the presence of a B chromosome in A. scabripinnis (Teleostei, Characidae). Cytogenet Cell Genet 74:70-75.

Associate Editor: Luiz Antoni Carlos Bertollo

License information: This is an open-access article distributed under the terms of the Creative Commons Attribution License, which permits unrestricted use, distribution, and reproduction in any medium, provided the original work is properly cited. 